Journal Plus Education, ISSN: 1842-077X, E-ISSN (online) 2068-1151 Vol XIX (2018), No. 1. pp. 199-206

\title{
THE ACCURACY OF PEDAGOGICAL LANGUAGE AND OF THE PEDAGOGICAL APPROACH - AN IMPERATIVE REQUIREMENT OF EDUCATIONAL REFORM
}

\author{
Rodica Mariana NICULESCU, PhD, \\ University Transilvania of Brasov, Romania \\ rodica_niculescu@yahoo.co.uk, \\ rodicanic@unitbv.ro
}

\begin{abstract}
This paper comes to add a new contribution to the same set of reflections about curriculum and the curriculum reform implications in the real life. The starting point is rooted in a day to day seen reality which must become a genuine concern for all the responsible educational factors all over the world. The methodology of teaching, as an essential structural element of the learning situation, the core issue of curriculum concept, is the focus of the analysis this time. The selected ideas of the paper come from an indepth and long-term observation of the educational practice of the author as a professor for future specialists in education and evaluator of teachers involved in the specific Romanian process of reaching the first degree in education. A number of dysfunctions and weaknesses of the educational practice are presented in the area of using the teaching methodology and some argued explanations are provided.
\end{abstract}

Key words: curriculum reform; educational reform; teaching methodology focused on learning;

1. The current context of the reform (in the world and in our country)

At a time of the generation that has created a glorious title in wearing kneebroken trousers, and broken to elbows clothes, the need to reform education all over the world is visible not only in schools and amphitheaters but also in every corner the street. The significance of the blunt pants or broken clothes because of a hard work was lost in the darkness of the specific attitude of this era in which" to pretend to do" has become a daily reality that takes on more and more ingenious forms. To the voluntarily destroyed clothes, the omnipresent phone that powerfully steals the eyes of the people wearing clothes in the travesty is added. It appears that in the street there is no longer 
any eye to seeing the size of holes in pants, stockings or jackets. But it does not seem to matter. Important seems to be only to wear the fashionable holes and to keep the eyes fixed on the little screen. This is the reality of life nowadays.

An impressive number of official documents and statements highlight the concern about the education for the next generation and stress the intentions to offer genuine possibilities to ensure access to basic education for all. This is an essential part of the 2030 Agenda for Sustainable Development, for instance, which outlines how countries, working with UNESCO and global partners, can translate commitments into action.

A surface study or an in-depth analysis of what it is happening in the area of national educational systems show a wide range of measures aiming to develop the education process within the national boundaries according to concrete and specific possibilities. Theoretically, everything appears to be correct and with chances to reach the declared goals. Practically, the street and the day to day life show a consistent gap between intention and reality.

One of the reasons for existing this gap is what I can name as the" banner of pretending" which seems to become a poison of our time. The hungry for receiving points and for building fat personal portfolios, the excessive bureaucracy cover the concern of the teachers about what is really important in their work, the care for the effective educational act. The teachers training itself (both stages: pre-service and in-service) appear to be influenced by this superficiality. The direct reflection of all these is obviously seen through the results on students' competencies.

This paper comes to add a new contribution to the same set of reflections about curriculum and the curriculum reform implications in the real life. It focuses the attention on one of the five structural elements of the learning situation as the core issue of the curriculum: the teaching methodology. In the context, an analysis of how teachers choose and use this methodology, how they understand the place and the role of it within the curriculum context is to be scrutinized.

\section{Teaching-learning methods a structural element of major importance of the learning situation}

A previous paper from this cycle has already shown the pyramid of the curriculum as a visual representation of the structure of a learning situation. 


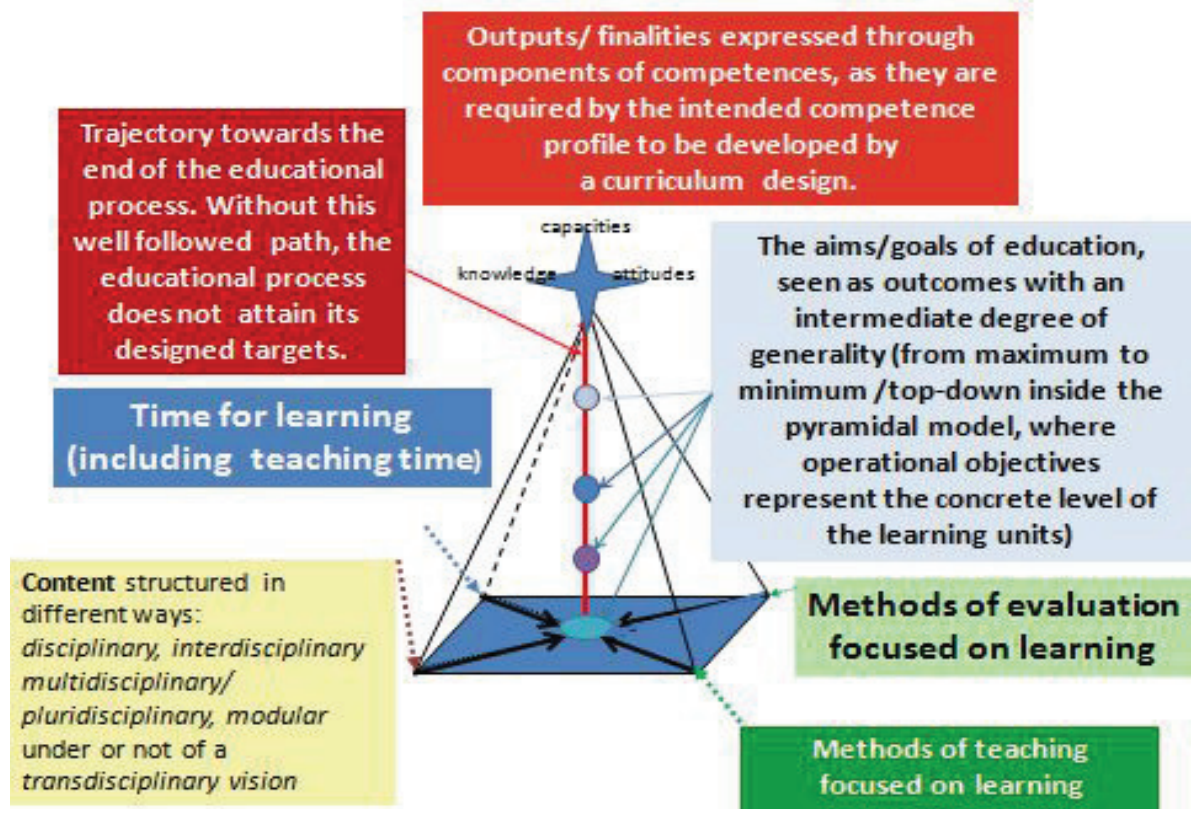

Fig. 1 Pyramidal model of the learning situation as core el issue of curriculum

This time the analysis starts with the methodology of teaching considered in a functional connection with the other elements of the learning situation structure and having as fundamentals, the available and appropriate means and tools for teaching. The fig. 2 shows these connections.

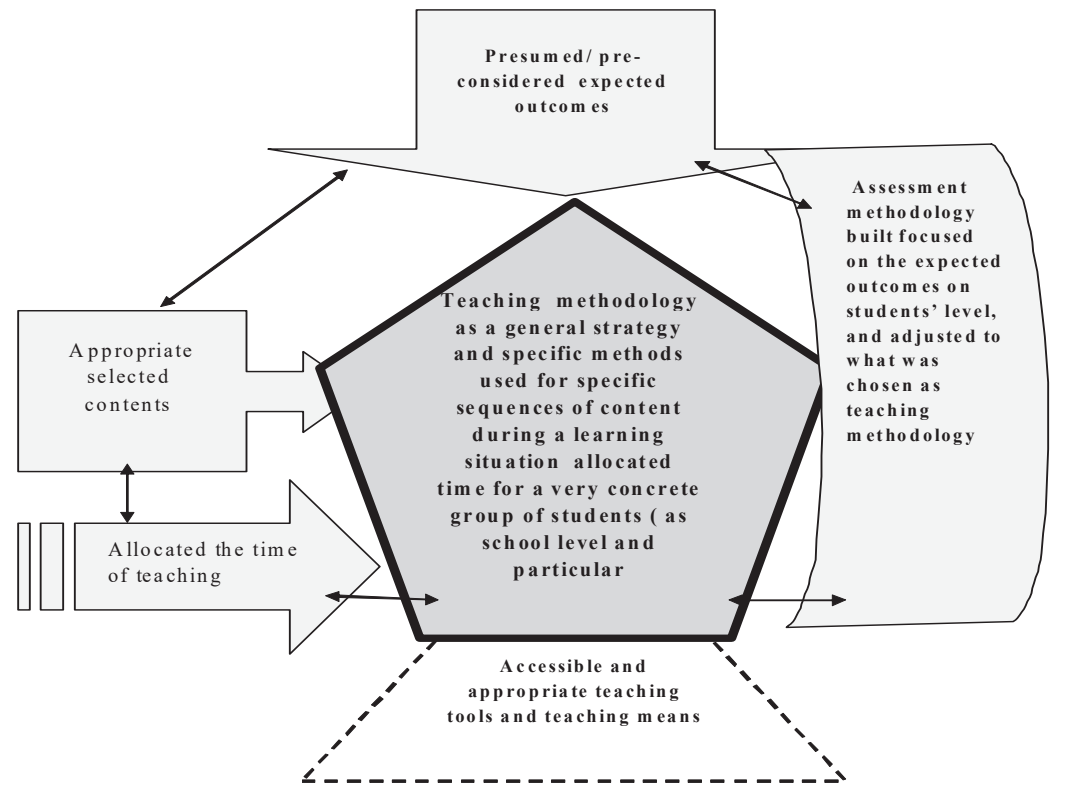

Fig. 2 Methodology of teaching within the context of the learning situation 


\subsection{Location and relations with other fundamental structural elements}

The fig. 2 highlights the determination of teaching methodology by the other structural elements of a learning situation. The teaching methodology is firstly determined by the expected outcomes that are the most important aspect to be reached because they will be the aspects taken into account by a final assessment of the students' achievements. The contents are selected from what the national curriculum recommends, but they have to be appropriate vehicles leading to the development of those students' competencies considered as expected outcomes. The delivery of these contents must be done by using an appropriate teaching methodology, chosen with a strong focus on the concrete students' learning, aiming to develop the expected competencies but, in the same time, according to the available and appropriate teaching tools and means. The allocated time for teaching focused on students' learning is another constraint to be taken into account.

\subsection{Implicit relationships with other elements}

The available teaching tools and means are not a core element of the learning situation structure but they are important determinants of the selection when it is about the teaching methods. On the other side, the space of learning, the specificity of students -teacher relationship, the ethos of the school and the genuine support from the families and community are other important determinants for the selection of the teaching methodology. Behind all these, the vision and the quality of teachers training for using appropriate teaching methodology come to influence in a very interesting and strong way the quality of the educational process.

\section{Incertitude, confusion versus apparent brilliance in addressing didactic teaching methods}

The reality of nowadays, attentively observed during my activity as professor and evaluator of teachers (within the specific Romanian context of obtaining the first degree in education), or during the professional visits abroad highlights several common aspects that appear as characteristics of the educational reality. The more one talks about the necessity of using modern didactic strategies and methods, the more the confusion seems to become prevalence.

The practice of education is abundant of complicated projects. Procedures for the pedagogical design that have become a kind of Procust' bed is the bases of this new fashion in designing the educational process. The little understood in their essence these procedures are, the more they are used in design documents with tenacity worthy of a better cause. 
Firstly, they are strongly time-consuming; they became factors of a negative motivation for the essence of the educational work on one side, and stimulating factors to promote the form without substance. Thus, the" banner of to pretend" insinuates itself in this essential level of teaching activity. Several other confusions and misunderstandings are to be highlighted. Methods of organizing learning are confused and merged with the teachinglearning methods

Any learning situation implies generic student organization and successive reorganizations for each sequence the learning situation, depending on what is aimed at implementing each of the sequences

Active methods are treated as synonymous with interactive ones.

Activism is targeted at each student who, during the teaching process, must actively manifest not necessarily in the motor plan (as is misunderstood as behavioral activism at the level of movement), but especially in the cognitive plane. The pupil must be faced with aspects that he/she thinks about, bringing knowledge from his / her memory, decoding the new information, answering, even in internal language, questions raised by the teaching process. The active participation of the student is possible in the circumstances when the teaching really catches the attention; it leads him/her to participate with interest in what is happening in the class. And this strongly depends on the teaching methodology.

Sometimes, the tasks involved in the teaching process require collaboration between students, performing group/ team activities in order to give a response. The response could involve the cognitive and/ or sometimes the physical involvement of all members of the group, on well-defined task sequences for each of the students. Only in this case can we talk about interactive methods.

Tasks such as:" read and highlight... choose and put it in a hierarchy", addressed individually are aimed at student activism but not interactivity.

Tasks of type: "carry a dialogue on the theme X and extract the basic ideas from what the interlocutor says... or work in a group of three / five a drawing with the theme $\mathrm{Y}$ and then build a description in words of what you drew ... " are tasks engaging interactivity.

The pedagogical projects abound by specifying the use of critical thinking methods but only taken as a name and not as the essence of their significance. Thus, methods such as star explosion, bunch method, cube method, etc. are ubiquitously present in projects, but a careful analysis of how they are designed and implemented demonstrates the lack of understanding of the very purpose of each of them.

A simple use of the cube as a mean to establish the person who must give an answer does not mean to use the cube method. The drawing on the paper of different sort of branched schemas without a clear connection among the 
structural elements does not mean to aim the essence of the bunch method. These methods have, each of them, very well defined educational purposes focused on engaging students in specific cognitive approaches based on inductive or deductive cognitive strategies. The given name of each method is less important but the essence must be understood. Unfortunately, it seems that the names are remembered and considered and the essence is totally or partially forgotten.

Questioning in terms of a problem is confused with problem-solving.

The problem solving asks for applying an already known algorithm or, in a more creative stage to combine already known algorithms in order to solve a given problem.

Questioning in terms of a problem seems to be more a principle of an active teaching strategy where the teachers know to create a problematic situation when they highlight a contradiction between what the students know and what it is asked, or put under the analytical approach.

For example, we can imagine the study of Lucian Blaga's Poetry: Light of Heaven. Poetry, in essence, deals with the perpetual and omnipresent struggle of opposites. Working with teenagers, the teacher can ask them to analyze the two verses"I have no heart in my head,/ neither brains aren't in my hear", and to connect them with the concept of rational love. This could generate a problematic situation, because of the intrinsic contradiction of the terms, that would lead to profound analyzes and fruitful debates, both intellectually and ethically and aesthetically. The creation of the problematic situation means only to develop a cognitive and emotional context with huge potential for the effective using of other methods of teaching focused on learning. In the specified example, could be used as learning teachingmethods the argued debate (in the form of court trial methods for instance), reflection, a demonstration using examples etc.

The literature abounds with materials about the modern methodology of teaching, sometimes good materials, or, other times, translations done by specialists in language but not in pedagogy that contain interesting but dangerous errors.

The in-service training of teachers is often done by people who don't show an in-depth understanding of the pedagogical meaning of what they teach. On the other side the beneficiary, the other teachers, are very content to memorize some ideas, to copy different procedures without a real concern for understanding them, and finally but not the last, to receive the credits and the documents for the personal portfolios. And this is all. The genuine development of their teaching competencies is not a part of this equation.

All these issues are springs of the previously presented confusions and of the gaps between ideal and reality of the educational field. 
Something should be done. And probably the change of the philosophy about the teachers training could be the starting point of the change of teachers' mentality. This must, obviously, connected to a new way of understanding of the necessity that essence must be the king, not the perishable form.

This paper wants to be another pleading for renouncing to the brilliance of the surface in the educational process and to focus our attention to the essential aspects of what we are doing and of what is to be done.

Doing this in a proper manner can be a strong premise of street cleaning of knee-broken trousers, and broken into elbows clothes, and to replace these pretended and prefabricated proofs of a faked hard work, with some genuine proofs of a competent and intelligent work. This is the real seed of a bright future.

\section{References: (selection)}

Bruffee, Kenneth A.(1993). Collaborative Learning: Higher Education, Interdependence, and the Authority of Knowledge. Baltimore: Johns Hopkins University Press

Cerghit, I. (1980). "Metode de învăţare”, E.D.P., Bucureşti, 1980

Ciortea, M. (2011). Didactica limbii și literaturii române în gimnaziu și liceu, Calitate, inovare, comunicare în sistemul de formare continuă a didacticienilor din învăţământul superior, Alba Iulia.

De Bono E. (2003). "Gândirea laterala”, Ed. Curtea' Veche, 2003

De Bono E. (2009), “Cursul de gândire al lui' Edward de Bono”, Ed. Curtea Veche,

Dumitru, I. A. (2000). “Dezvoltarea gândirii critice şi învăţarea eficientă", Editura de Vest, Timişoara,

Hesse-Biber S.(2015), The problems and prospects in the teaching of mixed methods research, International Journal of Social Research Methodology Volume 18, 2015 - Issue 5: The Teaching and Learning of Social Research Methods

Kolb, David A. (1984). Experiential Learning:Experience as the Source of Learning and Development. Englewood Cliffs, New Jersey: Prentice Hall, Inc.

Radu, I.T.( 1995). „Moduri şi forme de organizare a procesului de învăţământ”, în Cerghit, I., Radu, I.T., Popescu, E., Vlăsceanu, L., Didactica, EDP, Bucureşti.

Schean, I. (2004). "Gândirea critică: metode active de predare- învăţare", Editura Dacia Educaţional

Voiculescu, E. (2002). Metodologia predării-învăţării şi evaluării, Editura Ulise, Alba Iulia

Weston A. (2008), “Creativitatea în gândirea' critică”, Ed. All 
Journal Plus Education, ISSN: 1842-077X, E-ISSN (online) 2068-1151 Vol XIX (2018), No. 1. pp. 199-206

https://www.didactic.ro/revista-electronica/revista-electronica-didactic-roissn-aa844-4679-februarie-2-aa2/gandirea-critica-si-creativa-in-contextulinvatamantului-modern

Gândire critică și creativă (2012) Universitatea Tehnică- Cluj Napoca

http://asl.utcluj.ro/asl/files/Gandire ppt.pdf 